\title{
Genetic Variability, Heritability and Genetic Advance for Yield and its Contributing Traits in Rice (Oryza sativa L.) under Salinity and Normal Condition
}

\author{
Preeti Kumari $^{1 *}$, M.P. Chauhan ${ }^{1}$, Archana Devi ${ }^{1}$, O.P. Verma ${ }^{1}$, \\ R. Dwivedi ${ }^{1}$ and D. K. Dwivedi ${ }^{2}$
}

${ }^{1}$ College of Agriculture, Department of Genetics and Plant Breeding, Narendra Deva University of Agriculture and Technology, Kumarganj, Ayodhya - 224229 U P India ${ }^{2}$ Department of Plant Molecular Biology and Genetic Engineering, Narendra Deva University of Agriculture and Technology, Kumarganj, Ayodhya-224229, U. P. India

*Corresponding author

\section{Keywords}

Genetic variability,

Heritability,

Genetic advance,

Rice

Article Info

Accepted:

12 June 2019

Available Online:

10 July 2019

\section{A B S T R A C T}

The experiment was carried out during Kharif, 2016-2017 with forty nine genotypes of rice under two soil condition viz. salinity and normal. Analysis of variance revealed highly significant differences among the genotypes for all the characters under both the conditions. The high estimates of phenotypic and genotypic coefficient of variation under salinity condition were estimated for panicle bearing tillers per plant and grain yield per plant while under normal condition for biological yield per plant, harvest-index, spikelet fertility, days to $50 \%$ flowering, plant height, grains per panicle and spikelets per panicle. The characters in salinity condition viz., grain yield per plant, spikelets per panicle, flag leaf area, biological yield per plant, plant height and L:B ratio and in normal condition spikelet fertility, days to $50 \%$ flowering, plant height, grains per panicle, spikelets per panicle exhibited high heritability estimates coupled with high genetic advance as per cent of mean.

\section{Introduction}

Rice (Oryza sativa L.) is the most important staple food crop for more than 60 per cent ofthe global population and forms the cheapest source of food energy and protein. By origin, the crop is native to South East Asia with two cultivated (Oryza sativa and Oryza glaberrima) and 22 wild species. It belongs to the genus Oryza and grass family Poaceae. The crop is cultivated under a wide range of agro-ecological situations. Globally, it is grown in an area of $162.71 \mathrm{~m}$ ha with an annual production of $741.47 \mathrm{~m}$. $\mathrm{t}$. and 
productivity of $45.56 \mathrm{q} \mathrm{ha}^{-1}$. It is the most important food crop of India with world ranking first in area (43.8 $\mathrm{m}$ ha) and second to China in production (FAO, 2014). In India, rice is cultivated with an annual production of $110.15 \mathrm{~m}$. t. and average productivity of 25.50 q/ha (2016-17, Department of Agri., Coop. \& Farmers Welfare). In Uttar Pradesh it covers an area of $1.04 \mathrm{~m}$ ha with a production of 3.04 $\mathrm{m} t$ tonnes and average productivity of 29.13 q/ha 2015-2016, (India today). With the growth of world's population towards 10 billion by 2050 , the demand for rice will grow faster than for other crops. Apart from drought, salinity is also major cause of crop yield loss and it is increasing due excess use of fertilizers and industrialization. The present investigation was carried out to study the importance of genetic variability, heritability and genetic advance for genotypes under salinity and normal condition. Genetic variability is of greatest interest to the plant breeder as it plays a vital role in framing successful breeding programme. Heritability of a metric character is a parameter of particular significance to the breeder as it measures the degree of resemblance between the parents and the off springs and its magnitude indicates the heritability with which a genotype can be identified by its phenotypic expression, while genetic advance aids in exercising the necessary selection pressure.

\section{Materials and Methods}

The experimental material comprised of forty nine germplasm of rice (Oryza sativa L.) grown in Genetics \& Plant Breeding Research Farm and Student Instructional Farm of N.D. University of Agriculture and Technology, Kumarganj, Ayodhya U.P., India, during Kharif, 2016-2017. The recommended agronomic and plant protection measures were followed in order to raise a normal crop. The $\mathrm{pH}, \mathrm{EC}$ and ESP were 8.9, $0.28 \mathrm{dSm}^{-1}$ and
$68 \%$, respectively for saline soil. Observations on thirteen different quantitative characters viz., days to $50 \%$ flowering, plant height $(\mathrm{cm})$, flag leaf area $\left(\mathrm{cm}^{2}\right)$, panicle bearing tillers per plant, panicle length $(\mathrm{cm})$, spikelets per panicle, grains per panicle, spikelet fertility (\%), 1000- grains weight (g), L:B ratio, biological yield per plant (g), harvest-index $(\%)$ and grain yield per plant $(\mathrm{g})$ were recorded on five randomly selected competitive plants for each genotype except for days to 50\% flowering where data was recorded on plot basis during various phenophases of the crop. Mean values from the five randomly selected plants for each genotype were averaged and expressed as the mean of the respective character and considered for statistical analysis. Analysis of variance was computed based on Randomized Block Design for each of the character separately as per standard statistical procedure given by Panse and Sukhatme (1978). Heritability $\left(h^{2}\right)$ in the broad sense was calculated according to the formula given by Hanson et al., (1956). Phenotypic and genotypic coefficients of variation (PCV and GCV) were computed according to Burton, and De Vane (1952) and genetic advance in percent of mean Johanson et al., (1955).

\section{Results and Discussion}

Analysis of variance for the experiment (Table 1a and b) involving a set of 49 germplasm lines of rice for thirteen characters viz., days50\% flowering, plant height, flag leaf area, panicle bearing tillers per plant, panicle length, spikelets per panicle, grains per panicle, spikelet fertility, 1000- grains weight, L:B ratio, biological yield per plant, harvestindex, grains yield per plant revealed highly significant differences among the genotypes for all the characters under both the conditions indicating sufficient variability existed in the present material selected for the study and indicating the scope for selection of suitable 
initial breeding material for crop improvement. The results pertaining to genetic parameters viz., phenotypic coefficient of variation (PCV), genotypic coefficient of variation (GCV), broad sense heritability $\left(\mathrm{h}^{2} \mathrm{bs}\right)$ and genetic advance as percent of mean for all the thirteen characters are furnished in (Table 2a) and Figure 1a under salinity condition and (Table 2b) and Figure 1b under normal condition. It is apparent from the (Table 2a and b) that the magnitude of phenotypic coefficient of variation was higher than the corresponding genotypic coefficient of variation for all the traits indicating that there was an influence of the environment. Similar findings were earlier reported by Saha et al., (2019). Under salinity condition this could be seen from the highest magnitude of both PCV (25.40\%) and GCV (23.20\%) for grains yield per plant, and under normal condition highest magnitude of both PCV $(129.97 \%)$ and GCV (89.84\%) for spikelets per panicle, grains per panicle (106.12, 74.46 $\%$ ), plant height $(95.86,76.08 \%)$, days to $50 \%$ flowering $(87.71,77.00 \%)$, spikelet fertility $(81.75,60.81 \%)$, biological yield per plant $(\mathrm{g})$ $(58.74,37.15 \%)$, harvest-index \% (37.68, $31.13 \%$ ), respectively suggesting that these characters showed apparent variations not only due to genotypes but also due to favorable influence of environment. Under salinity characters plant height $(10.67,10.22$ $\%)$, spikelets per panicle $(11.90,11.13 \%)$, grains per panicle $(13.79,13.19 \%)$, L: B ratio (14.71, $14.64 \%)$, harvest-index (\%) (17.52, $14.26 \%)$, and flag leaf area $(18.50,17.58 \%)$ were recorded for moderate magnitudes of both PCV and GCV, respectively and under normal condition characters grains yield per plant $(14.07,8.55 \%)$, panicle bearing tillers per plant $(10.32,6.59 \%)$ showed moderate estimates of PCV while GCV were recorded low for these characters. Under salinity the days to $50 \%$ flowering $(5.24,4.99 \%)$, spikelet fertility $(\%)(6.19,5.59 \%)$ and 1000- grains weight $(\mathrm{g})(7.99,7.93 \%)$ while under normal condition L: B ratio (2.81, $2.05 \%)$ showed lower magnitudes of both PCV and GCV, respectively. Similar results were reported by Umarani et al., (2017), Sandeep, et al., (2018) and Saha et al., (2019) for grain yield per plant, flag leaf area Divya et al., (2018) for number of productive tillers per plant, number of grains per panicle and seed yield per plant, Sandeep et al., (2018), Tiwari (2017) for grains per panicle and spikelet fertility Bhati et al., (2015) for days to 50\% flowering, Ketan and Sarkar (2014) for spikelet fertility, Konate et al., (2016), Kumar and Verma (2016) and Rashid et al., (2017) for panicle bearing tillers per plant, Khare et al., (2014) for plant height, panicle length and 1000 grain weight, Karthikeyan (2010) for grain yield per plant, biological yield per plant and grains per panicle. Under salinity condition the difference between the estimates of PCV and GCV were low for days to plant height, spikelets per panicle, grains per panicle, 1000 grain weight, L: B ratio and in normal condition for $\mathrm{L}: \mathrm{B}$ ratio which showed there by lesser role played by the environment in the expression of these characters.

The difference between the estimates of PCV and GCV was high under salinity condition for panicle bearing tillers per plant, panicle length, harvest-index, days to $50 \%$ flowering, flag leaf area, spikelet fertility, biological yield per plant, grain yield per plant and under normal condition for all characters except that for L: B ratio these indicated the significant role played by the environment in the expression of this character.

Heritability estimates revealed the heritable portion of variability present in different characters. The knowledge of heritability enables the plant breeder to decide the course of selection procedure to be followed under a given situation Li and Yan (1985). Under salinity condition most of the characters recorded high estimates of heritability. 
Table.1(a) Analysis of variance for randomized block design for13 characters in rice genotypes under salinity condition

\begin{tabular}{|c|c|c|c|}
\hline \multirow[t]{2}{*}{ Characters } & \multicolumn{3}{|c|}{ Sources of variation } \\
\hline & Replications & Treatments & Error \\
\hline d.f. & 2 & 48 & 96 \\
\hline Days to $50 \%$ flowering & 4.76 & $3520.49 * *$ & 237.50 \\
\hline Plant height (cm) & 35.74 & $12010.13 * *$ & 703.76 \\
\hline Flag leaf area $\left(\mathrm{cm}^{2}\right)$ & 5.87 & $2684.45 * *$ & 184.53 \\
\hline Panicle bearing tillers per plant & 1.05 & $285.07 * *$ & 260.11 \\
\hline Panicle length (cm) & 2.17 & $579.08 * *$ & 225.68 \\
\hline Spikelets per panicle & 23.48 & $26690.77 * *$ & 2426.94 \\
\hline Grains per panicle & 71.82 & $23105.41 * *$ & 1406.41 \\
\hline Spikelet fertility (\%) & 8.82 & $3031.70 * *$ & 421.83 \\
\hline 1000- grains weight (g) & 0.06 & $439.38 * *$ & 3.97 \\
\hline L:B ratio & 0.00 & $22.72 * *$ & 0.16 \\
\hline Biological yield per plant (g) & 0.58 & $8729.44 * *$ & 549.96 \\
\hline Harvest-index (\%) & 1.29 & $3814.44 * *$ & 1108.31 \\
\hline Grains yield per plant(g) & 8.87 & $1371.01 * *$ & 170.74 \\
\hline
\end{tabular}

$*$,** Significant at $5 \%$ and $1 \%$ probability levels, respectively.

Table.1(b) Analysis of variance for randomized block design for 13 characters in rice genotypes under normal condition

\begin{tabular}{|c|c|c|c|}
\hline \multirow[t]{2}{*}{ Characters } & \multicolumn{3}{|c|}{ Sources of variation } \\
\hline & Replications & Treatments & Error \\
\hline d. f. & 2.00 & $48.00 * *$ & 96.00 \\
\hline Days to $50 \%$ flowering & 21.56 & $5548.57 * *$ & 431.23 \\
\hline Plant height (cm) & 19.99 & $10718.20 * *$ & 1526.26 \\
\hline Flag leaf area $\left(\mathrm{cm}^{2}\right)$ & 4.03 & $2659.43 * *$ & 156.72 \\
\hline Panicle bearing tillers per plant & 0.51 & $352.99 * *$ & 171.71 \\
\hline Panicle length $(\mathrm{cm})$ & 2.10 & $407.43 * *$ & 185.07 \\
\hline Spikelets per panicle & 215.32 & $88474.73 * *$ & 6910.53 \\
\hline Grains per panicle & 214.34 & $61288.80 * *$ & 4306.79 \\
\hline Spikelet fertility (\%) & 7.62 & $2699.86^{* *}$ & 647.54 \\
\hline 1000- grains weight (g) & 0.01 & $400.69 * *$ & 8.35 \\
\hline L:B ratio & 0.00 & $24.35 * *$ & 0.55 \\
\hline Biological yield per plant (g) & 10.15 & $8897.39 * *$ & 624.56 \\
\hline Harvest-index (\%) & 9.42 & $802.15^{* *}$ & 683.47 \\
\hline Grains yield per plant(g) & 0.29 & $1784.87 * *$ & 149.33 \\
\hline
\end{tabular}

*,** Significant at $5 \%$ and $1 \%$ probability levels, respectively. 
Table.2(a) Estimates of general mean, range, phenotypic (PCV) and genotypic (GCV) coefficient of variation, heritability in broad sense $\left(h^{2} b\right)$ and genetic advance in per cent of mean for 13 characters in rice in salinity condition

\begin{tabular}{|c|c|c|c|c|c|c|c|c|}
\hline \multirow{2}{*}{\multicolumn{2}{|c|}{ Characters }} & \multirow{3}{*}{$\begin{array}{l}\begin{array}{l}\text { Grand } \\
\text { mean }\end{array} \\
97.48\end{array}$} & \multicolumn{2}{|c|}{ Range } & \multirow{3}{*}{$\begin{array}{l}\text { PCV } \\
\\
5.24\end{array}$} & \multirow{3}{*}{$\begin{array}{r}\text { GCV } \\
4.99\end{array}$} & \multirow{3}{*}{$\begin{aligned} \mathbf{h}^{2} \\
\\
90.52\end{aligned}$} & \multirow{3}{*}{$\begin{array}{r}\begin{array}{l}\text { GA in } \% \\
\text { of mean }\end{array} \\
9.77\end{array}$} \\
\hline & & & \multirow{2}{*}{$\begin{array}{l}\text { Min. } \\
77.67\end{array}$} & \multirow{2}{*}{ Max. } & & & & \\
\hline 1. & Days to $50 \%$ flowering & & & & & & & \\
\hline 2. & Plant height (cm) & 88.06 & 70.20 & 111.53 & 10.67 & 10.22 & 91.7 & 20.16 \\
\hline 3. & Flag leaf area $\left(\mathrm{cm}^{2}\right)$ & 24.13 & 16.75 & 36.52 & 18.50 & 17.58 & 90.35 & 34.43 \\
\hline 4. & $\begin{array}{l}\text { Panicle bearing tillers per } \\
\text { plant }\end{array}$ & & 6.49 & 12.50 & 20.75 & 11.06 & 28.43 & 12.15 \\
\hline 5. & Panicle length $(\mathrm{cm})$ & & 17.62 & 25.68 & 10.64 & 8.10 & 57.94 & 12.69 \\
\hline 6. & Spikelets per panicle & 119.46 & 102.09 & 171.82 & 11.90 & 11.13 & 87.5 & 21.45 \\
\hline 7. & Grains per panicle & 94.59 & 64.81 & 141.84 & 13.79 & 13.19 & 91.39 & 25.97 \\
\hline 8. & Spikelet fertility (\%) & 79.14 & 59.27 & 85.78 & 6.19 & 5.59 & 81.68 & 10.41 \\
\hline 9. & 1000- grains weight (g) & & 18.61 & 24.75 & 7.99 & 7.93 & 98.66 & 16.23 \\
\hline 10. & L:B ratio & & 2.17 & 3.47 & 14.71 & 14.64 & 98.95 & 29.99 \\
\hline 11. & Biological yield per plant (g) & 38.77 & 27.20 & 59.33 & 20.71 & 19.76 & 91.11 & 38.86 \\
\hline 12. & Harvest-index $(\%)$ & 33.38 & 22.47 & 41.78 & 17.52 & 14.26 & 66.23 & 23.90 \\
\hline 13. & Grains yield per plant(g) & 12.88 & 7.92 & 20.48 & 25.40 & 23.20 & 83.39 & 43.64 \\
\hline
\end{tabular}

Table.2(b) Estimates of general mean, range, phenotypic (PCV) and genotypic (GCV) coefficient of variation, heritability in broad sense $\left(h^{2} b\right)$ and genetic advance in per cent of mean for 13 characters in rice in normal condition

\begin{tabular}{|c|c|c|c|c|c|c|c|c|}
\hline \multirow{2}{*}{\multicolumn{2}{|c|}{ Characters }} & \multirow{3}{*}{$\begin{array}{r}\begin{array}{l}\text { Grand } \\
\text { mean }\end{array} \\
87.71\end{array}$} & \multirow{2}{*}{\multicolumn{2}{|c|}{ Range }} & \multirow{3}{*}{$\begin{array}{r}\text { PCV } \\
87.71\end{array}$} & \multirow{3}{*}{$\begin{array}{r}\text { GCV } \\
77.00\end{array}$} & \multirow{3}{*}{$\begin{array}{l}\mathbf{h}^{2} \\
89.18\end{array}$} & \multirow{3}{*}{$\begin{array}{ll}\begin{array}{l}\text { GA in } \\
\% \\
\text { mean }\end{array} & \begin{array}{l}\text { of } \\
13.50\end{array} \\
\end{array}$} \\
\hline & & & & & & & & \\
\hline 1. & Days to $50 \%$ flowering & & $\begin{array}{l}\text { Min. } \\
77.00\end{array}$ & $\begin{array}{l}\text { Max. } \\
113.00\end{array}$ & & & & \\
\hline 2. & Plant height (cm) & 95.86 & 76.08 & 114.13 & 95.86 & 76.08 & 81.30 & 16.11 \\
\hline 3. & Flag leaf area $\left(\mathrm{cm}^{2}\right)$ & 25.16 & 17.79 & 37.77 & 25.16 & 17.79 & 91.65 & 33.19 \\
\hline 4. & Panicle bearing tillers per plant & 10.32 & 6.59 & 12.81 & 10.32 & 6.59 & 50.91 & 19.40 \\
\hline 5. & Panicle length (cm) & 23.34 & 19.05 & 26.00 & 23.34 & 19.05 & 53.15 & 9.52 \\
\hline 6. & Spikelets per panicle & 129.97 & 89.84 & 194.37 & 129.97 & 89.84 & 89.13 & 36.36 \\
\hline 7. & Grains per panicle & 106.12 & 74.46 & 159.11 & 106.12 & 74.46 & 90.15 & 37.35 \\
\hline 8. & Spikelet fertility (\%) & 81.75 & 60.81 & 87.53 & 81.75 & 60.81 & 70.98 & 8.62 \\
\hline 9. & 1000- grains weight (g) & 22.78 & 18.77 & 25.64 & 22.78 & 18.77 & 96.94 & 14.77 \\
\hline 10. & L:B ratio & 2.81 & 2.05 & 3.68 & 2.81 & 2.05 & 96.67 & 29.44 \\
\hline 11. & Biological yield per plant (g) & 37.15 & 23.73 & 58.74 & 37.15 & 23.73 & 90.16 & 40.65 \\
\hline 12. & Harvest-index (\%) & 37.68 & 31.13 & 42.53 & 37.68 & 31.13 & 30.99 & 5.44 \\
\hline 13. & Grains yield per plant(g) & 14.07 & 8.55 & 23.46 & 14.07 & 8.55 & 88.42 & 47.43 \\
\hline
\end{tabular}


Fig.1(a) Graph showing distribution of genetic parameters for yield and yield components in rice in salinity condition

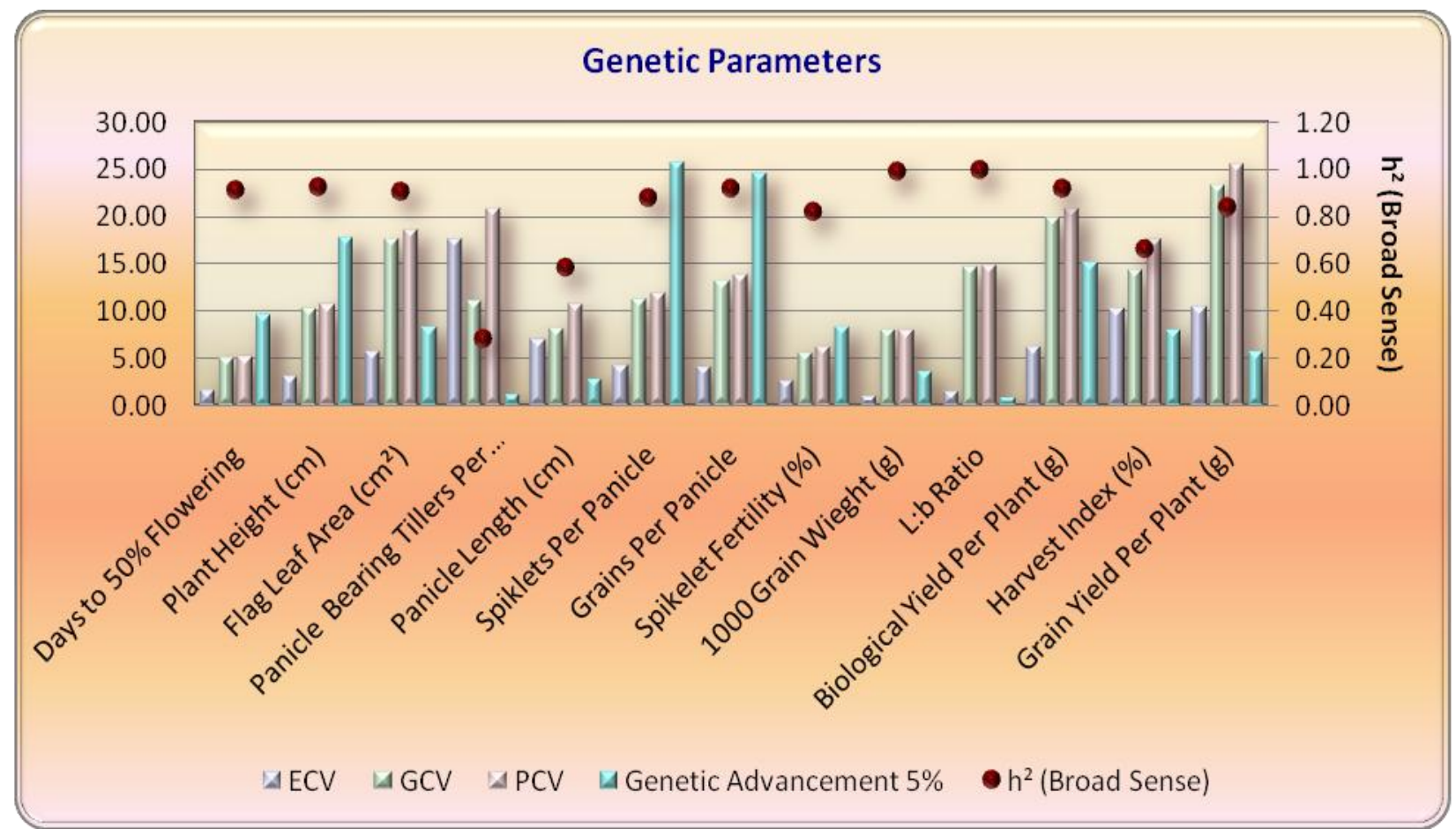

Fig.1(b) Graph showing distribution of genetic parameters for yield and yield components in rice in normal soil condition

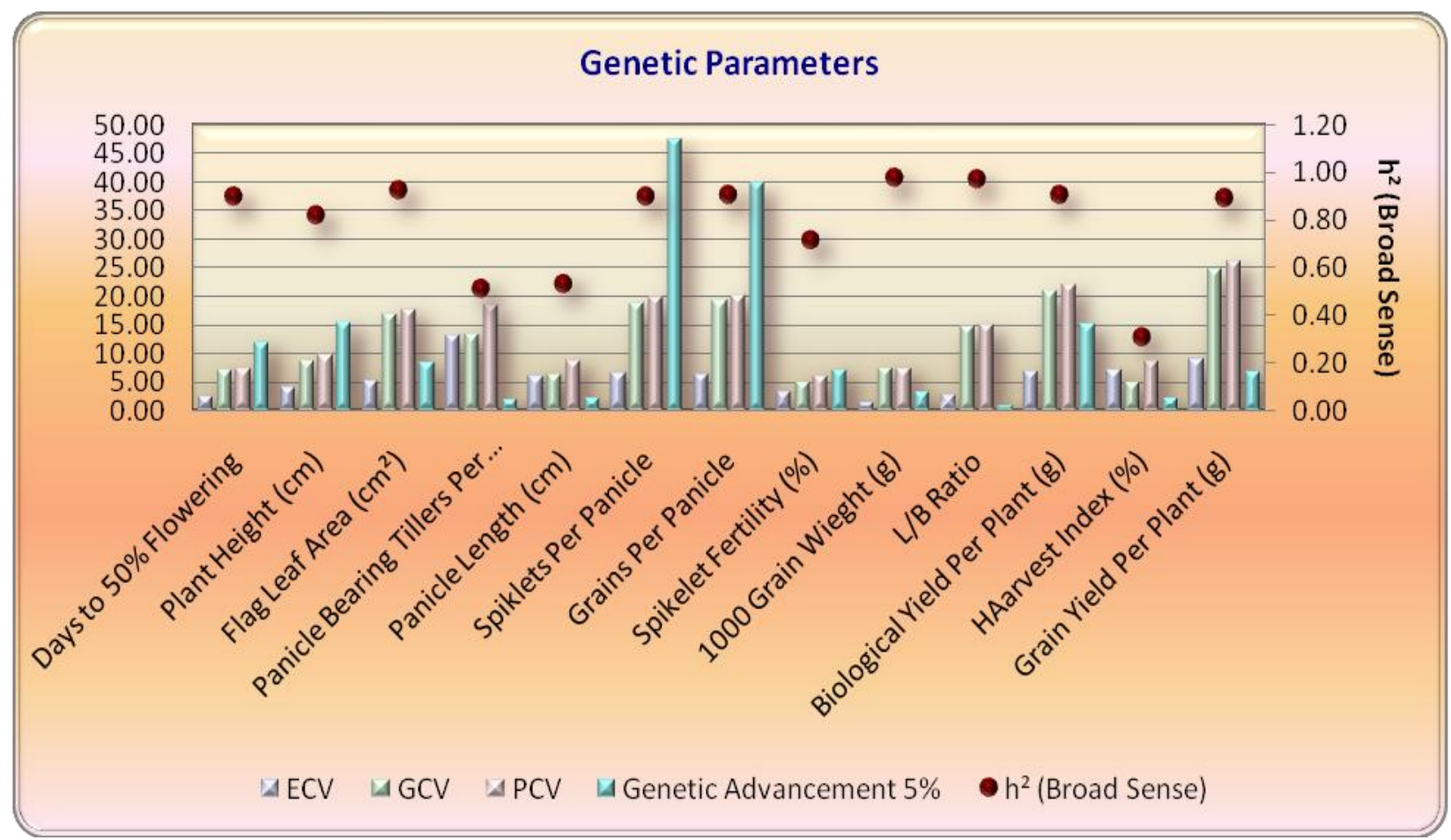


Broad sense heritability estimates ranged lowest $(28.43 \%)$ for panicle bearing tillers per plant to highest $(98.95 \%)$ for $\mathrm{L}$ : B ratio. The characters like spikelet fertility $(81.68 \%)$, grain yield per plant $(83.39 \%)$, spikelets per panicle $(87.5 \%)$, flag leaf area $(90.35 \%)$, days to $50 \%$ flowering $(90.52 \%)$, biological yield per plant $(91.11 \%)$, grains per panicle (91.39\%), plant height $(91.7 \%), 1000$ grain weight $(98.66 \%)$ and L:B ratio $(98.95 \%)$ exhibited high heritability. Whereas under normal condition it ranged lowest (30.99\%) for harvest-index to highest $(96.94 \%)$ for 1000- grains weight. The characters like spikelet fertility (70.98\%), days to $50 \%$ flowering (89.18\%), plant height (81.30\%), grains per panicle $(90.15 \%)$ and spikelets per panicle $(89.13 \%)$ exhibited high heritability. The results are in consonance with the reports given by Saha et al., (2019) for flag leaf area, number of grains per panicle and number of filled grains per panicle. Sandeep et al., (2018) for spikelet fertility, plant height, single plant yield, number of grains per panicle, number of tillers per hill, pollen viability, number of productive tillers per hill, panicle length and 1000 grain weight, Divya et al., (2018) for productive tillers per plant, 1000 grain weight, number of grains per panicle and seed yield per plant, Devi et al., (2016) for flag leaf area, spikelets per panicle, grains per panicle, 1000-grain weight, biological yield per plant, harvest-index and grain yield per plant under saline condition. Rashid et al., (2017) for days to $50 \%$ flowering, days to maturity, plant height, 1000 grain weight and single plant yield. Prasad et al., (2017) for panicle length, number of tillers per hill and number of productive tillers per hill. All the characters recorded high estimates of heritability indicating that they were least influenced by the environmental effects, however selection for improvement of such characters may not be useful, because broad sense heritability is based on total genetic variance which includes additive, dominant and epistatic variances. Thus, the heritability values along with estimates of genetic advance would be more reliable than heritability alone Johnson et al., (1967). The genetic advance expressed as percent of mean values under salinity condition ranged lowest (9.77) for days to $50 \%$ flowering to $(43.64 \%)$ grains yield per plant. The characters, plant height $(20.16 \%)$, spikelets per panicle $(21.45 \%)$, harvest-index $(23.90 \%)$, grains per panicle $(25.97 \%)$, L: B ratio (29.99\%), flag leaf area (34.43\%), biological yield per plant $(38.86 \%)$ and grain yield per plant (43.64\%) recorded high magnitude of genetic advance as percent of mean. The character spikelet fertility (\%) (10.41), panicle bearing tillers per plant (12.15\%), panicle length $(12.69 \%)$ and 1000 grains weight $(16.23 \%)$ showed moderate magnitude of genetic advance as percent of mean. The trait days to $50 \%$ flowering $(9.77 \%)$ recorded the lowest magnitude of genetic advance as percent of mean. Under normal condition it ranged low $(5.44 \%)$ for harvest-index to high $(47.43 \%)$ for grain yield per plant. The characters, grain yield per plant (47.43\%), biological yield per plant $(38.86 \%)$, grains per panicle $(37.35 \%)$, spikelets per panicle $(36.36 \%)$, flag leaf area $(33.19 \%)$, L:B ratio $(29.44 \%)$, recorded high magnitude of genetic advance as percent of mean. The characters, panicle bearing tillers per plant (19.40\%), plant height (16.11\%), 1000- grains weight $(14.77 \%)$, days to $50 \%$ flowering $(13.50 \%)$ showed moderate magnitude of genetic advance as percent of mean. Whereas panicle length (9.52\%), spikelet fertility $(8.62 \%)$ and harvest-index $(5.44 \%)$ recorded the lowest magnitude of genetic advance as percent of mean. Similar results for high genetic advance were reported by Gokulakrishnan et al., (2014) and Prasad et al., (2017) for single plant yield Khare et al., (2014) for plant height, number of productive tillers per hill and panicle length, Kumar and Verma (2016) for 1000 grain weight, Devi et 
al., (2016) for flag leaf area, spikelets per panicle, grains per panicle, 1000-grain weight, biological yield per plant, harvestindex and grain yield per plant, Divya et al., (2018) for number of productive tillers per plant, 1000 grain weight, number of grains per panicle and seed yield per plant, Sandeep et al., (2018) for spikelet fertility, plant height, single plant yield, number of grains per panicle, number of tillers per hill, number of productive tillers per hill, panicle length and 1000 grain weight, Saha et al., (2019) for flag leaf area, number of grains per panicle and number of filled grains per panicle. All the characters recorded high estimates of heritability indicating that they were least influenced by the environmental effects, however, selection for improvement of such characters may not be useful, because broad sense heritability is based on total genetic variance which includes additive, dominant and epistatic variances.

Thus, the heritability values along with estimates of genetic advance would be more useful on correlating selection criteria than heritability alone Johnson et al., (1967). High heritability with moderate genetic advance was recorded under salinity condition for spikelet fertility, 1000- grains weight and under normal condition for days to $50 \%$ flowering, plant height and 1000- grains weight. These traits appear to be under the control of both additive and non-additive gene actions. The present finding is in consonance with the findings of Gokulakrishnan et al., (2014), Ketan and Sarkar (2014), Khare et al., (2014) and Konate et al., (2016). High heritability with low genetic advance was recorded under salinity for days to $50 \%$ flowering and under normal condition for panicle length, spikelet fertility, harvest-index indicating non additive gene action. The high heritability is being exhibited due to favourable influence of environment rather than genotype and hence, selection for such traits may not be rewarding. Similar results were reported by Bhati et al., (2015). In the present investigation, high heritability coupled with high genetic advance was observed under salinity condition for grain yield per plant, spikelets per panicle, flag leaf area, biological yield per plant, grains per panicle, plant height and L:B ratio and under normal condition were observed for grains per panicle, spikelets per panicle. Thus, these traits are predominantly under the control of additive gene action and hence these characters can be improved by pedigree method of breeding. Similar, results for high heritability coupled with high genetic advance for various traits were earlier reported by Gokulakrishnan et al., (2014), Ketan and Sarkar (2014), Harsh et al.,(2015), Bhati et al., (2015), Bhinda et al., (2017) and Rashid et al., (2017) for plant height and number of grains per panicle, Khare et al., (2014) for panicle length, Prasad et al., (2017) for number of tillers per hill and number of productive tillers per hill, Khare et al.,(2014) and Kumar and Verma (2016) for 1000 grain weight, Kishore et al., (2015) and Rohit et al., (2017) for single plant yield. In conclusion, high estimates of PCV and GCV were recorded for grains yield per plant in salinity and for biological yield per plant, harvestindex, spikelet fertility, days to $50 \%$ flowering, plant height, grains per panicle and spikelets per panicle under normal condition which provides considerable variability and offers scope for genetic improvement through selection. Further high heritability coupled with high genetic advance were observed under salinity condition for grains yield per plant, spikelets per panicle, flag leaf area, biological yield per plant, grains per panicle, plant height and L:B ratio and normal condition high heritability coupled with high genetic advance in per cent of mean were observed for grains per panicle, spikelets per panicle which indicated the role of additive gene action in controlling the traits, hence 
pedigree method of breeding will be a rewarding one to improve the traits under investigation.

\section{References}

Bhati, M, Suresh BG and Aishwarya SR (2015). Genetic variability, correlation and path coefficient for grain yield and quantitative traits of elite rice (Oryza sativa L.) genotypes at Uttar Pradesh. Elec. J. of Pl. Bre. 6 (2): 586-591.

Bhinda, MS, Karnwal MK and Choudhary MK (2017). Estimates of genetic variability, heritability and genetic advance for yield contributing and quality traits in advance breeding lines of rice (Oryza sativa L.). Int. J. of Adv. Biotech. Res.7 (2): 229-233.

Burton, GW (1952). Quantitative inheritance in grasses. Proc. of sixth Inter. Grassland Cong. 1: 227-281.

Department of Agriculture, Cooperation \& Farmers Welfare, Ministry of Agriculture \& Farmers Welfare Government of India, annual report 2017-18 http://agricoop.gov.in

Devi, A, Srivastava, K, Kumari, P and Dwivedi, R (2016). Genetic variability in rice under salinity condition. Trends in Biosci. 9(9) 564-567

Divya, J, Damodar, Ch. Raju, Subba Rao, LV and Aparna, K. (2018). Genetic variability studies in genetically diverse rice genotypes. Int.J.Curr. Microbiol.App.Sci. 7(04): 1169-1172.

Gokulkrishnan, J, B SK, and Prakash M. (2014). Variability studies for some yield and quality traits in rice (Oryza sativa L.). Pl Arch. 14(1): 533-536.

Hanson, CH, Robinson, HF and Comstock, RE (1956). Biometrical studies of yield in segregating population of Korean Lespedeza. Agron. J. 45: 268-272.

Johnson, HW, Robinson, HF and Comstock, RE (1955). Estimates of genetic and environmental variability in soybean. Agron. J. 47: 314-318.

Johnson, SC (1967). Hierarchical clustering schemes. Psychometrika. 32: 241-254.

Karthikeyan, P, Anbuselvam, Y, Elangaimannan, $\mathrm{R}$ and Venkatesan, $\mathrm{M}$ (2010). Variability and heritability studies in rice (Oryza sativa L.) under coastal salinity. Elec. J. of Pl. Bre. 1(2): 196-198.

Ketan, R and Sarkar, G (2014). Studies on variability, heritability, genetic advance and path analysis in some indigenous Aman rice (Oryza sativa L.).J. of Crop and Weed.10 (2): 308-315.

Khare, R, Singh, AK, Eram S and Singh, PK (2014). Genetic variability, association and diversity analysis in upland rice (Oryza sativa L). SAARC $J$ of Agri. 12(2): 40-51

Konate, AK, Adama, Z, Honore, K, Ambaliou, S and Alain, A. (2016). Genetic variability and correlation analysis of rice (Oryza sativa L.) inbred lines based on agro morphological traits. African J. of Agril. Res. 11(35): 3340- 3346.

Kumar, A and Verma, OP (2016). Genetic variability, heritability and genetic advance studies in rice (Oryza sativa L.) under sodic soil. Res. in Environ. and Life Sci. 9(2): 149-151.

Li, CM and Yang, KC (1985). Studies on inheritance of quantitative characters for plant type in some inbred lines of maize. Scien. Agri. Sini. 9: 28-36.

Panse, VG and Sukhatme, PV (1978). Statistical methods for agricultural workers. Indian Cou. of Agril. Res. Publ. New Delhi. Pp. 235-246.

Prasad, KR, Krishna, KVR, Bhave, MHV and Rao, LVS (2017).Genetic variability, heritability and genetic advance in boro rice (Oryza sativa L.) germplasm. Inter. J. Curr. Micro. Applied Sci. 6(4): 12611266. 
Rashid, MM, Nuruzzaman, M, Hassan L and Begum, SN (2017). Genetic variability analysis for various yield attributing traits in rice (Oryza sativa L.) genotypes. J. Bangladesh Agri. Uni. 15(1): 15-19.

Rohit, Y, Rajpoot, P, Verma, OP, Singh, PK, Singh P and Pathak, V (2017). Genetic variability, heritability and genetic advance in rice (Oryza sativa L.) for grain yield and its contributing attributes under sodic soil. J. Pharmaco. Phytochem. 6(5): 1294-1296.

Saha, SR, Hassan, L, Haque, MA, Islam, MM and Rasel, M (2019). Genetic variability, heritability, correlation and path analyses of yield components in traditional rice (Oryza sativa L.) landraces. J. of Bangladesh Agri. Uni. 17(1): 26-32.

Sandeep, S, Sujatha, M, Subbarao, LV and Neeraja, CN (2018). Genetic variability, heritability and genetic advance studies in rice (Oryza sativa L.). Int. J. Curr. Microbiol. App. Sci., 7(12): 3719-3727.

Tiwari, JK (2017). Association analysis and selection strategies for various yield contributing traits in rice genotypes. Applied Bio. Res. 19(1): 35-40.

Umarani, E, Radhika, K, Padma V and Subbarao, LV (2017). Variability, heritability and genetic advance for agromorphological and grain quality parameters in landraces of rice (Oryza sativa L.). Env. Eco. 35(3): 1682-1687.

www.indiatoday.in

\section{How to cite this article:}

Preeti Kumari, M.P. Chauhan, Archana Devi, O.P. Verma, R. Dwivedi and Dwivedi, D.K. 2019. Genetic Variability, Heritability and Genetic Advance for Yield and its Contributing Traits in Rice (Oryza sativa L.) under Salinity and Normal Condition. Int.J.Curr.Microbiol.App.Sci. 8(07): 1296-1305. doi: https://doi.org/10.20546/ijcmas.2019.807.154 